\title{
Does the new international trade regime leave room for industrialization policies in the middle-income countries?
}

Working Paper No. 22

\section{Alisa Di Caprio}

and

Alice Amsden

Policy Integration Department

World Commission on the Social Dimension of Globalization

International Labour Office

Geneva

May 2004 


\section{Copyright (C) International Labour Organization 2004}

Publications of the International Labour Office enjoy copyright under Protocol 2 of the Universal Copyright Convention. Nevertheless, short excerpts from them may be reproduced without authorization, on condition that the source is indicated. For rights of reproduction or translation, application should be made to the Publications Bureau (Rights and Permissions), International Labour Office, CH-1211 Geneva 22, Switzerland. The International Labour Office welcomes such applications.

Libraries, institutions and other users registered in the United Kingdom with the Copyright Licensing Agency, 90 Tottenham Court Road, London W1T 4LP [Fax: (+44) (0)20 7631 5500; email: cla@cla.co.uk], in the United States with the Copyright Clearance Center, 222 Rosewood Drive, Danvers, MA 01923 [Fax: (+1) (978) 750 4470; email: info@copyright.com] or in other countries with associated Reproduction Rights Organizations, may make photocopies in accordance with the licences issued to them for this purpose.

ISBN 92- 2-116134-X (printed version)

ISBN 92- 2-116135-8 (web version)

First published 2004

Cover:

The designations employed in ILO publications, which are in conformity with United Nations practice, and the presentation of material therein do not imply the expression of any opinion whatsoever on the part of the International Labour Office concerning the legal status of any country, area or territory or of its authorities, or concerning the delimitation of its frontiers.

The responsibility for opinions expressed in signed articles, studies and other contributions rests solely with their authors, and publication does not constitute an endorsement by the International Labour Office of the opinions expressed in them.

Reference to names of firms and commercial products and processes does not imply their endorsement by the International Labour Office, and any failure to mention a particular firm, commercial product or process is not a sign of disapproval.

ILO publications can be obtained through major booksellers or ILO local offices in many countries, or direct from ILO Publications, International Labour Office, CH-1211 Geneva 22, Switzerland. Catalogues or lists of new publications are available free of charge from the above address, or by email: pubvente@ilo.org

Visit our website: $\underline{\text { www.ilo.org/publns }}$ 





\section{Does the new international trade regime leave room for industrialization policies in the middle-income countries?}

\section{Contents}

Foreword

Page

Preface.

iv

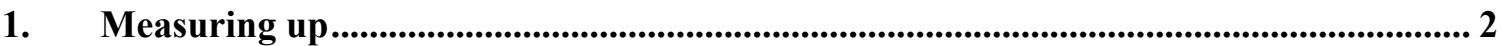

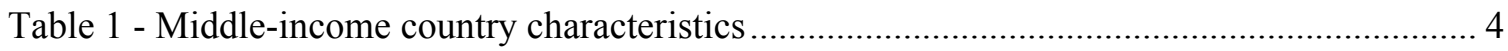

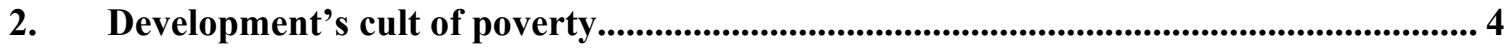

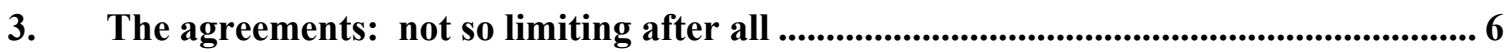

3.1 Agreement on Trade-Related Aspects of Intellectual Property Rights (TRIPs) ......... 6

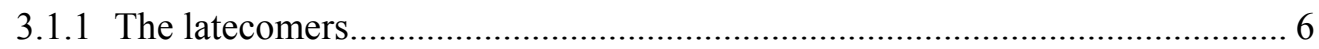

3.1.2 The potential industrializers ..................................................................... 7

3.2 Agreement on Trade-Related Investment Measures (TRIMs) _................................. 8

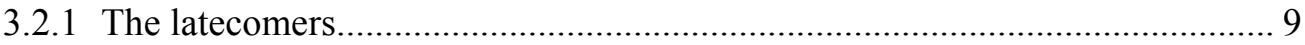

3.2.2 The potential industrializers ................................................................. 9

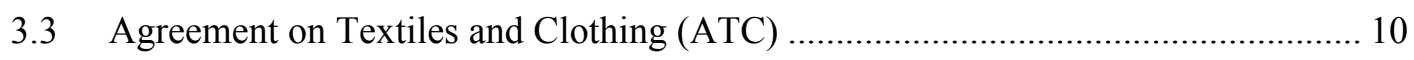

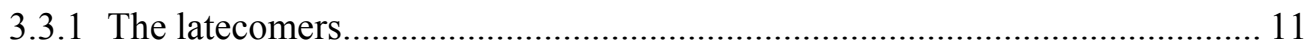

3.3.2 The potential industrializers .................................................................. 11

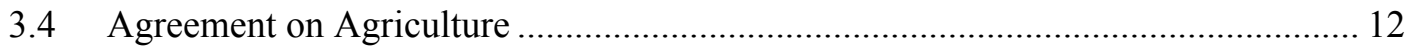

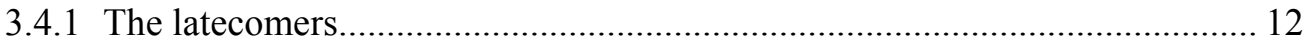

3.4.2 The potential industrializers ................................................................... 12

3.5 Agreement on the Application of Sanitary and Phytosanitary Measures (SPS) ....... 13

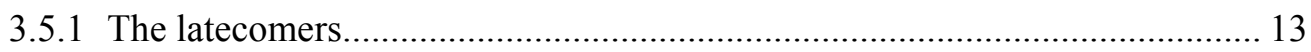

3.5.2 The potential industrializers .................................................................... 13

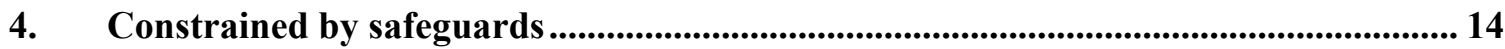

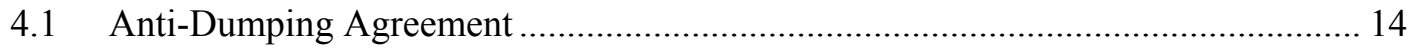

4.2 Agreement on Subsidies and Countervailing Measures .......................................... 15

4.2.1 Non-actionable subsidies for research and redevelopment ........................... 15

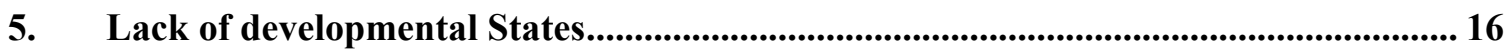

Table 2 - Changes in the product structure of selected developing country exports (\% share) .... 18

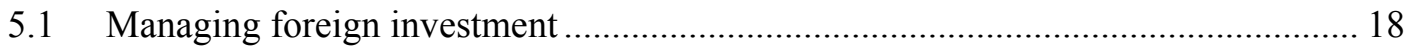

5.2 Regional integration agreements ...................................................................... 19

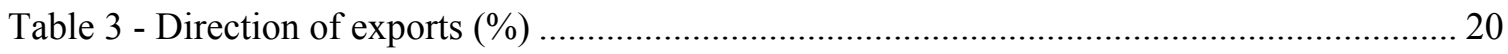

6. Towards a post-Washington Consensus trade regime................................................. 20

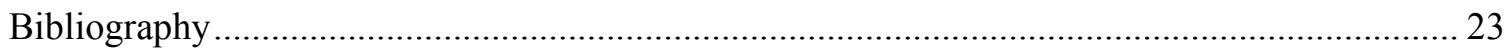





\title{
Foreword
}

In February 2002, the ILO established an independent World Commission on the Social Dimension of Globalization, co-chaired by President Tarja Halonen of Finland and President Benjamin Mkapa of Tanzania and comprising 26 eminent commissioners from a wide range of walks of life and different parts of the world, each serving in their individual capacity. Its broad goals were: to identify policies for globalization that reduce poverty, foster growth and development in open economies, and widen opportunities for decent work; to explore ways to make globalization inclusive, so that the process can be seen to be fair for all, both between and within countries; to promote a more focused international dialogue on the social dimension of globalization; to build consensus among key actors and stakeholders on appropriate policy responses; and to assist the international community forge greater policy coherence in order to advance both economic and social goals in the global economy.

The report of the World Commission, A fair globalization: Creating opportunities for all, was released on 24 February 2004. It is available on the Commission's website www.ilo.org/public/english/wcsdg/index.htm.

A secretariat was established by the ILO to support the Commission. Among other tasks, it compiled information and commissioned papers on different aspects of the social dimension of globalization. The aim was to provide the Commission with documentation and data on a wide range of options and opinions concerning subjects within its mandate, without committing the Commission or individual Commissioners to any particular position on the issues or policies concerned.

Material from this background work is being made available as working papers, as national and regional reports on meetings and dialogues, and in other forms. Responsibility for the content of these papers and publications rests fully with their authors and their publication does not constitute an endorsement by the World Commission or the ILO of the opinions expressed in them.

\author{
Gerry Rodgers \\ Director \\ Policy Integration Department
}






\title{
Preface
}

The Technical Secretariat to support the World Commission on the Social Dimension of Globalization first prepared a synthesis of ILO activities on the Social Dimension of Globalization (published as Working Paper No. 1 in this series). Documentation on the work and outcomes of other major commissions, an ideas bank, a database and knowledge networks of experts and social actors were subsequently developed. These networks have dealt with several topics, including: inclusion at the national level for the benefits of globalization to reach more people; local markets and policies; cross-border networks of production to promote decent work, growth and development; international migration as part of the Global Policy Agenda; international governance (including trade and finance); the relationship between culture and globalization; and values and goals in globalization. Gender and employment aspects were addressed throughout this work. The Reports on the Secretariat's Knowledge Network Meetings are available on the Commission's web site or in a special publication from the ILO (ISBN 92-2-115711-1).

During the course of these activities, a number of substantive background papers were prepared, which are now made available for wider circulation in the Policy Integration Department's Working Paper series (Nos. 16 to 38), as well as on the Commission's website.

Ms. Di Caprio and Prof. Amsden, of the Massachusetts Institute for Technology (MIT) in Boston argue in this paper that the changeover from the General Agreement on Tariffs and Trade (GATT) to the World Trade Organization (WTO) regime in 1994 was accompanied by a contraction of the scope available to member Governments to conduct domestic industrial policy. This limit is particularly poignant for the set of mid-technology countries that are on the verge of industrialization. Much of the rationale behind the stringent constraints of the WTO agreements is found in the Washington Consensus view of development that has dominated the international stage for the past few decades. The Consensus is that development should be pursued through poverty alleviation, free markets and foreign investment. There is little support for policies that directly promote technological capacity-building or the industrialization that drove the development of the latecomer industrialising countries.

The Washington Consensus reasons that technological development and industrial diversification will occur naturally as a result of trade. This is deduced from the tenet of endogenous growth theory that, since goods embody technological knowledge, importing them will engender positive spillover effects .The authors argue that these arguments are not borne out by the experiences of the latecomer industrialising countries and investigate how the development policies used by successful late industrializers would fare under the current WTO regime. They conclude that success is possible if the potential industrializers are proactive in building their technical capacity through the use of all the tools available to them to seek out loopholes and circumvent the new barriers that the WTO has placed in the path of industrialization.

\author{
Rolph van der Hoeven \\ Manager, Technical Secretariat \\ World Commission on the Social Dimension of Globalization
}

May 2004 



\title{
Does the new international trade regime leave room for industrialization policies in the middle-income countries?
}

\begin{abstract}
Brazil, 1960. The Government imposed local content requirements on domestically produced automobiles in order to build up the domestic parts manufacturing sector. Content requirements were accompanied by incentives such as subsidies and preferential access to foreign exchange. This led to an efficient and technologically advanced set of parts suppliers in the country (Shapiro, 1994).
\end{abstract}

\begin{abstract}
Indonesia, 1996. The Government imposed local content requirements on domestically produced automobiles as part of the Indonesian national car project in 1993. By 1996, the measure was sniffed out by the European Communities and a dispute panel was requested. ${ }^{1}$ By 1998, the Indonesian Government had eliminated all elements of the requirements that did not comply with World Trade Organization (WTO) obligations.
\end{abstract}

The changeover from the General Agreement on Tariffs and Trade (GATT) to the World Trade Organization (WTO) regime in 1994 was accompanied by a contraction of the scope available to member Governments to conduct domestic industrial policy. This limit is particularly poignant for the set of mid-technology countries that are on the verge of industrialization, a group that we call the "potential industrializers."2 Many of them are looking to the most recent group of successfully industrializing nations, such as Brazil and the Republic of Korea, as policy models. However, as the example above illustrates, many of the key strategies that were used by the so-called "late industrializers" are in fact no longer available to this next group. ${ }^{3}$

Much of the rationale behind the stringent constraints of the WTO agreements is found in the Washington Consensus view of development that has dominated the international stage for the past few decades. The Consensus is that development should be pursued through poverty alleviation, free markets and foreign investment. There is little support for policies that directly promote technological capacity-building or the industrialization that drove the development of the latecomer countries. The wholesale adoption of the Washington Consensus by both the international financial institutions and the international community as a whole has turned their policy focus away from sustainable industrial development and towards strategies of poverty alleviation. For those countries on the verge of industrialization, in particular, this has limited their prospects for industrial development.

\footnotetext{
${ }^{1}$ DS54 Indonesia: Certain measures affecting the automobile industry (Complaint by the European Communities).

${ }^{2}$ This includes countries such as Ecuador, Egypt, Islamic Republic of Iran, Pakistan, Peru and South Africa.

${ }^{3}$ This group of "late industrializers" includes countries such as Brazil, India, Republic of Korea, Taiwan (China) and Thailand.
} 
The Washington Consensus reasons that technological development and industrial diversification will occur naturally as a result of trade. This is deduced from the tenet of endogenous growth theory that, since goods embody technological knowledge, importing them will engender positive spillover effects (Grossman and Helpman, 1991). The reasoning continues that countries benefit more from spillovers the more open their economies are and the more skilled their populations (Coe, Helpman and Hoffmaister, 1997). Yet these arguments are not borne out by the experiences of the latecomers. In Latin America, where foreign investment was relatively weakly regulated, the ability of countries to generate domestic proprietary knowledge was limited, compared to the highly regulated investment regimes in Asia.

The method of evaluation adopted in this paper is to see how the development policies used by successful late industrializers would fare under the current WTO regime. This is supplemented by evidence from interviews with various country representatives of both latecomers and potential industrializers. The strategies of the late industrializers are used as a benchmark for understanding the options available to the second group of countries, since these countries share the characteristics that were required for the successful industrialization of the latecomers. An assumption that is made in this paper is that the methods used by the late industrializers are the most efficient means of achieving industrialization for the potential industrializers. Based on this assumption, we conclude that success is possible if the potential industrializers are proactive in building their technical capacity through the use of all the tools available to them to seek out loopholes and circumvent the new barriers that the WTO has placed in the path of industrialization.

\section{Measuring up}

In the 1970s, the late industrializers implemented a set of development strategies that were home-grown and predicated on domestic policies of export promotion, conditional subsidies and protected domestic industries. In short, control mechanisms. ${ }^{4}$ While the precise policies followed in Latin America and Asia were different, both aimed at the same pay-off - to change the industrial mix so as to promote export diversification and grow domestic industries. The international trading environment the latecomers faced was one in which the GATT gave little explicit recognition to the special trade problems of developing countries, but nor was it particularly invasive in their domestic policies (Tussie, 1987: 17). Under the GATT regime, the latecomers were able not only to increase their exports, but also to direct investment in such a way that they could change their mix of exports.

The latecomers were able to industrialize rapidly as a result of two key historical factors. The first was pre-war manufacturing experience. This gave the countries an understanding of technology and a degree of industrial infrastructure. The other factor was that their populations were relatively well educated. This is important because technology transfer is inefficient without absorption capability in the receiving country.

\footnotetext{
${ }^{4}$ For a complete discussion of their strategies, see Amsden (2001).
} 
The middle-income countries discussed in this paper have comparable backgrounds to the latecomers. As an example of manufacturing experience, until the 1970s Nigeria had a thriving trade regime with the West African market in goods that were diversified around oil, such as nails, detergents and corrugated iron sheeting. An example of the existence of educated workers is the fact that China is among the top six countries of origin of foreignborn scientists and engineers employed in the United States (NSF, 2001). But while the fulfilment of these prerequisites is necessary, it is not a sufficient condition for industrialization. An example of this is the fact that, while the Nigerian population as a whole is well educated, many nationals reside outside the country and do not therefore contribute to the country's absorptive capacity.

Another aspect of the latecomers is also missing in many of the potential industrializers. The latecomer governments were actively involved in managing domestic development strategies. However, of the potential industrializers, few have a sound development plan that extends beyond "seeing where the investment goes". This is troublesome, since history has shown that unfettered investment does not in itself lead to the technology transfer needed to kick start industrialization. A tangible example of the problems associated with laissez-faire openness is that it appears that the more openness the developing countries maintain, the less likely are foreign investors to conduct research and development (R\&D) in those countries, as the United States limits high technology and knowledge-intensive spillovers. ${ }^{5}$

Despite their limitations, the potential industrializers are in some ways better positioned than their predecessors to use trade to their developmental advantage. These countries have greater bargaining power on the world stage as active members of the international regulatory institutions, and are direct beneficiaries of popular protests against the problems relating to globalization. They are not afraid to assert their political leverage in trade affairs. This was evident recently when Pakistan demanded higher textile quotas in return for cooperation in Afghanistan. ${ }^{6}$ This leverage is furthered by the fact that many countries in this second group have oil resources, a useful bargaining chip. Political leverage has a key role to play as countries gear up for industrialization in a newly constrained environment.

Table 1 presents some of the statistical differences and similarities between the late industrializers and the potential industrializers. GDP levels in the group of potential industrializers are lower than in the late industrializers. However, their levels of foreign direct investment (FDI) tend to be higher, and their levels of R\&D are comparable. This suggests that it is necessary to take a closer look at the composition of FDI and R\&D to see how they compare to the situation of the late industrializers. This aspect is dealt with only briefly in this study, as the focus is on the international regulatory environment.

\footnotetext{
${ }^{5}$ Amsden, Tschang and Goto (2001) point out that multinational firms tend to conduct little R\&D outside their home base, and also that investments in $R \& D$ are highest in the developing countries in which businesses are nationally controlled.

6 "US may lift curbs on Pakistani textile quota", Asia Pulse. 8 February 2002.
} 
Table 1 - Middle-income country characteristics

\begin{tabular}{|c|c|c|c|}
\hline & $\begin{array}{r}\text { GDP b } \\
2001 \\
\text { (US\$ } \\
\text { billion) }\end{array}$ & $\begin{array}{r}\text { FDI } \\
(\% \text { GDP }) \\
2000\end{array}$ & $\begin{array}{r}\text { FDI } \\
(\% \text { GDP }) \\
\text { mid-1990s }\end{array}$ \\
\hline \multicolumn{4}{|l|}{ Late industrializers } \\
\hline Korea, Rep. of & 423.0 & 13.7 & $2.82 \mathrm{e}$ \\
\hline India & 485.2 & 4.1 & $0.73^{c}$ \\
\hline Taiwan, China & 282.0 & 9.0 & $1.80^{\mathrm{a}}$ \\
\hline Mexico & 621.0 & 16.9 & $0.33^{d}$ \\
\hline Brazil & 502.5 & 33.1 & $0.81^{\mathrm{e}}$ \\
\hline \multicolumn{4}{|l|}{ Potentials } \\
\hline Egypt & 92.4 & 21.1 & $0.22^{\mathrm{e}}$ \\
\hline Nigeria & 40.9 & 49.1 & n.a. \\
\hline Tunisia & 20.0 & 58.8 & $0.30^{f}$ \\
\hline South Africa & 113.3 & 34.5 & $0.70^{b}$ \\
\hline Ecuador & 18.0 & 51.0 & $0.2^{f}$ \\
\hline Peru & 54.1 & 18.5 & n.a. \\
\hline Costa Rica & 16.2 & 32.8 & $0.21^{\mathrm{a}}$ \\
\hline Guatemala & 20.5 & 18.0 & n.a. \\
\hline Iraq & 27.9 & n.a. & n.a. \\
\hline Iran, Islamic Rep. of & 71.9 & 2.4 & $0.48 c$ \\
\hline China & & 32.3 & $0.06^{f}$ \\
\hline Pakistan & 58.7 & 11.2 & n.a. \\
\hline
\end{tabular}

Source GDP: Economist Intelligence Unit Country Profiles 2002

Source FDI: UNCTAD (2002a)

Source R\&D: UNESCO, Statistical Yearbook 1999 ( $a=1991, b=1992 \ldots f=1997)$

n.a. $=$ not available

\section{Development's cult of poverty}

A Brazilian official recently quipped that industrial policy has become something that "we can't do because of the WTO, and we shouldn't do because of the Washington Consensus."

During the heyday of the late industrializers, development and industrialization were interchangeable terms. Development was something that countries strove for in order to raise the standards of living of their populations and improve their economic growth rates.

\footnotetext{
${ }^{7}$ Interview by Di Caprio (Geneva, December 2002).
} 
One of the primary ways of accomplishing this was through industrialization. To that end, the Republic of Korea enforced the allocation of licenses to trading companies in exchange for compliance with export targets (Amsden, 1990). And India and Taiwan (China) imposed prohibitive performance standards on foreign firms to discourage their operation in key sectors (Amsden, 2001). These were the ways that the latecomers targeted domestic firms and guided foreign investment in such a way that it would best benefit the development of national industries so as to reduce their dependence on imported technologies and inputs.

During the early industrialization of the latecomers, there was an ongoing debate about what constituted the best development strategy. The Dependency School was on its way out, and an influential study by Bhagwati and Krueger helped it through the door (Bhagwati and Krueger, 1973). As import substitution was discredited, export promotion became the favoured policy recommendation of the international financial institutions. As more countries reached the middle stages of development, the focus of the institutions that were providing financial support for development strategies moved to alleviating conditions of poverty, rather than creating the conditions for industrial evolution. This new thinking became ingrained as the Washington Consensus, and by the time of the Uruguay Round it was firmly in place as the "correct" development strategy.

The Consensus immediately took root in the basic policies of some of the major regulatory institutions. In the Single Undertaking of 1994, many of the new agreements embedded elements of the Consensus. In 1995, the World Bank redefined its understanding of development as being focused on poverty alleviation (World Bank, 1995). By writing the Consensus into the text of their policy goals and agreements, the regulatory institutions were effecting a change in how development would thenceforth be treated. It was the beginning of a cult of poverty in terms of the strategies encouraged to spur development.

In terms of development defined as poverty alleviation, the WTO does not in fact limit the scope of member countries to pursue development policies. And as the title Doha Development Agenda elucidates, the WTO does make some effort to encourage development. In these terms, the WTO could almost be called development-friendly.

So why the protests against the "anti-development" policies propagated by the WTO? The answer lies in the fact that development is not just poverty alleviation. To a middle-income country looking at the success of the latecomers, development is closely tied to the ability to industrialize. As a representative from Pakistan has pointed out, the benefits that countries gain from increased market access yield immediate monetary results, such as more jobs for workers in the beneficiary countries. On the other hand, the poverty alleviation strategies encouraged by the World Bank do not necessarily promote knowledge creation and therefore do not immediately or directly benefit recipient countries. ${ }^{8}$

Where do we stand now? There is widespread dissatisfaction among advocates of both the poorest and of middle-income countries. As the century came to an end, many of the developing countries began to grumble that the promises made to them in exchange for signing on had not materialized (UNCTAD, 2002a). The Washington Consensus is under siege, but no other paradigm has yet come forth.

\footnotetext{
${ }^{8}$ Interview by Di Caprio (Washington DC, February 2003).
} 


\section{The agreements: not so limiting after all}

In this section, several of the main WTO agreements are examined to assess the extent to which they limit industrialization strategies as they were pursued by the latecomers. Since the potential industrializers group will not follow the exact strategies of the latecomers, the manner in which they perceive the agreements will then be examined, bringing out any strategies they have used to either benefit from or circumvent any limitations. What is found is a surprising dichotomy between the experiences of the late industrializers and the perceptions of the potential industrializers.

\subsection{Agreement on Trade-Related Aspects of Intellectual Property Rights (TRIPs)}

Intellectual property is one of the most controversial areas covered by WTO provisions. Under the Agreement on Trade-Related Aspects of Intellectual Property Rights (TRIPs), all signatories are required to implement standard patent and copyright protection procedures. Many countries have already done so, and those which have been slow to do so, such as Pakistan, have been prodded by the Dispute Settlement Mechanism (DSU). ${ }^{9}$

\subsubsection{The latecomers}

One of the most important aspects of the strategies of the late industrializers was the procurement of proprietary knowledge. This enabled them to develop domestic technological skill and promote national leading firms that were eventually able to compete internationally. Knowledge procurement occurred in a number of different ways, ranging from learning from skilled Italian immigrants in Brazil, to buying products and reverse-engineering them in the Republic of Korea.

Patent protection has never been well enforced in the developing countries. This has facilitated technology transfer and the growth of domestic technological capacity. By requiring member States to standardize patents and copyright laws, the TRIPs Agreement limits some of the scope for domestic firms to copy and imitate technologies that they need to learn as a take-off point for further capacity building.

The developmental role and subsequent fate of national pharmaceutical industries under the TRIPs Agreement provides a particularly clear example of the way in which TRIPs limits the ability of countries to increase their high technology and research capacity. Under the GATT, countries used weak intellectual property protection to produce cheap generic drugs for their domestic markets. Producing generic drugs was useful both for public health reasons and as a means of building up domestic pharmaceutical industries.

\footnotetext{
${ }^{9}$ For example: DS37 Portugal; DS36 Pakistan; DS79 and DS50 India.
} 
Pharmaceutical production enabled Brazil, for example, to obtain the manufacturing experience and research skills necessary to imitate progressively more sophisticated pharmaceutical products, including the AIDS cocktail. The acceptance of TRIPs meant that Brazil was expected to honour patents for drugs that were not yet licensed for generic production. This created a problem for the Brazilian Government's policy of providing the AIDS cocktail free to its citizens. This was an option because the Government had been able to produce the drugs domestically in a cheaper generic form. When TRIPs was implemented, this became prohibitively expensive.

In this particular instance, the Doha Round recognized that public health could not be put at stake for reasons of proprietary knowledge. Doha provided for compulsory licensing in cases of public health emergencies. While compulsory licensing helps in the public health field, it does little to revive the learning and technology transfer that was occurring as countries were making their own generic drugs. The first reason is because many pharmaceutical firms simply shut down when the TRIPs Agreement was implemented. ${ }^{10}$ The other is because in-country production as a result of compulsory licensing is impossible without a pre-existing industry. Brazil was lucky in that it was able to build capacity before TRIPs took effect and as a result could threaten to restart production. As the European Union pointed out in a recent Communication, for countries which do not dispose of manufacturing capacity, the right to grant a compulsory license remains a theoretical one. And finally, as the conclusion to the recent case in Brazil illustrates, when presented with the threat of compulsory licensing, international drug companies instead offered to provide the drugs at a steep discount. ${ }^{11}$ This means that TRIPs continues to discourage activities that may build up local capacity by giving established firms the ability to dump goods legally on the domestic market.

The TRIPs Agreement has a limiting effect on domestic firms in the latecomer countries, but is it conversely beneficial to international investors? A recent preliminary analysis of extended patent protection in Brazil shows that the greatest beneficiaries of recent changes in Brazilian legislation and the implementation of the TRIPs Agreement have been multinational companies, not Brazilian firms (Epsztein, 1998).

\subsubsection{The potential industrializers}

While the late industrializers are united in their cry that TRIPs is limiting to their development objectives, the countries that are currently industrializing have voiced a different set of opinions. In interviews, country representatives are not negative about the TRIPs Agreement. It seems that the degree of damage depends on the choice of contrapositive. While representatives from Peru and Ecuador complain that the technology transfers that were promised in return for assent have not materialized, neither have seen any major detrimental effects in terms of labour outcomes.

As mentioned earlier, many developing countries had nascent pharmaceutical industries that were shuttered as a result of TRIPs legislation. However, none of the countries in the group of potential industrializers claim that they were competitive, and they do not appear

\footnotetext{
${ }^{10}$ Interviews by Di Caprio (Geneva, December 2002).

${ }^{11}$ Interviews by Di Caprio (Geneva, December 2002).
} 
to be a large part of their development strategies. A representative from Pakistan also pointed out that for countries where the volume of generic drugs produced is low, there is little or no pressure from the international drug companies, which are focused more on the big producers, such as India and Brazil. ${ }^{12}$

While the focus here has been on the pharmaceutical industry, TRIPs also affects other industries, such as software. Indeed, in this case, one of the potential industrializers claims that TRIPs was the reason that this industry grew at all. Ecuador claims that TRIPs helped to cultivate its nascent software industry. Firms knew that their interests would be protected regardless of the political climate and therefore stayed even after there was a crisis. This is precisely the opposite effect that TRIPs is claimed to have had on India's software industry. In the case of India, by most accounts, the software industry grew as a result of weak intellectual property protection. It remains to be seen if growth will be significantly slowed by bringing Indian laws into conformity with international standards.

We conclude that TRIPs limits the ongoing industrial strategies of late industrializers. However, it is not clear that it has been detrimental to the group of potential industrializers. Indeed, given that as a cohort they tend to suffer from political instability, the balance of TRIPs needs to include both the constraints relating to licensing and the benefits derived from a fixed framework.

\subsection{Agreement on Trade-Related Investment Measures (TRIMs)}

This is the WTO agreement that most clearly limits the strategies of the successful industrializers. The Agreement on Trade-Related Investment Measures (TRIMs) grew out of the GATT-era case concerning the Canadian Foreign Investment Review Act (FIRA), in which a dispute settlement panel ruled that Canada could not give differential treatment to Canadian firms. ${ }^{13}$ At the time the case was being litigated, the developing countries threatened to block the panel decision, as they were aware that the result would directly affect their domestic policies, even though there were no developing countries party to the dispute. To avoid this outcome, the 1984 settlement includes a paragraph at the end indicating that it would not apply to developing countries. ${ }^{14}$ The TRIMs Agreement was the WTO's effort to bring the developing countries into compliance. But this time there was no offsetting paragraph.

The objectives of the TRIMs Agreement include "the expansion and progressive liberalisation of world trade and to facilitate investment across international frontiers so as to increase the economic growth of all trading partners, particularly developing country Members, while ensuring free competition". 15 The thinking is that the policies that many

\footnotetext{
${ }^{12}$ Interview by Di Caprio (Washington DC, February 2003).

${ }^{13}$ Canada, Administration of the Foreign Investment Review Act (BISD 30S/140, 1984).

14 "The Panel recognizes that in disputes involving less-developed contracting parties full account should be taken of the special provisions in the General Agreement relating to these countries." Panel Report. GATT FIRA Case, 7 February 1984: 5.2.

${ }^{15}$ Agreement on Trade-Related Investment Measures. Preamble.
} 
countries maintain respecting investment are distortionary and that, by removing distortions, free trade will lead to the efficient allocation of resources.

An important argument against this reasoning comes from the result of unfettered foreign investment. Levels of FDI in developing countries have been increasing over time, a fact that is hailed by many economists as bringing better technology and management. ${ }^{16}$ However, it cannot unequivocally be asserted that this is not happening at the expense of local talent. Much FDI is in the form of mergers and acquisitions (M\&A), which means that it is a de facto denationalization of domestic industries. The very top professional managers used to be domestic, but under an M\&A agreement they are likely to come from, or remain in, the institution's host country.

\subsubsection{The latecomers}

In specific terms, the TRIMs Agreement prohibits measures that: (a) require particular levels of local sourcing by an enterprise; (b) restrict the volume or value of imports which an enterprise can buy or use to the volume or value of products it exports; (c) restrict the volume of imports to the amount of foreign exchange inflows attributable to an enterprise; and (d) restrict the export by an enterprise of products, whether specified in terms of the particular type, volume or value of products or of a proportion of volume or value of local production.

All of the latecomers used measures in their development strategies that are now illegal under the TRIMs Agreement. And given their success, they would like to continue to use them. Brazil and India have recently put forward a proposal to reword the Agreement to allow exceptions for developing countries. Brazil, in particular, argues that there is no proof that TRIMS are distortionary and that prohibiting them is an example of the industrial countries "pulling the ladder up". This expression underscores the wide-ranging effects that limitations on investment measures can have. China, for example, has a history of limiting foreign investment to joint ventures. However, as a result of WTO accession, it has had to rework the laws on local content for all joint ventures in every part of the economy. TRIMs is having pervasive effects for the latecomers.

\subsubsection{The potential industrializers}

Countries in the group of potential industrializers do not claim to be significantly affected by the limits imposed by the TRIMs Agreement. This appears to be a result of the fact that at their current stage of development investment is welcome in any form, and is unlikely to be limited. However, interviews yielded two interesting facets of the potentials/latecomers dichotomy.

\footnotetext{
${ }^{16}$ See, for example, the introduction to Feldstein (1997).

${ }^{17}$ List of limits adapted from Weiler and Cho (1996). For a checklist of strategies used see Singh (1996: 184-185).
} 
The first is that, while the latecomers claim that the extension of the TRIMs Agreement's exceptions for developing countries is necessary and desirable, the potential industrializers disagree. Peru has gone so far as to say that the extensions demanded by the latecomers are unnecessary and will be opposed. This is because the TRIMs Agreement only allows for greater flexibility if the countries have domestic technological capacity. Since the latecomers have used TRIMs and can afford to maintain them, their capacity is understood. The potential industrializers do not have such capacity and so will be further disadvantaged the longer the latecomers are allowed to use these measures.

The second facet of the dichotomy is that many of the potential industrializers are covered by preferential trading agreements with large importing countries, such as the United States and the European Union. These preferential trading agreements by definition include local content requirements. This presents members with an escape hatch from limitations on that particular aspect of TRIMs. Ecuador mentioned that local content had been important in its auto industry. Rather than eliminating TRIMs-violating local content requirements on cars, Ecuador focused on the Andean region as a way of maintaining them. The United States was its largest auto export market, and the Andean Pact allows for reduced barriers for autos produced in the Andean region. Ecuador was therefore able to maintain its local content requirement by simply shifting it to a regional content requirement.

Like TRIPs, the TRIMs Agreement does not yet pose much of a limit on the group of potential industrializers as none of them has reached the stage of having the capacity to use such measures. It is an Agreement for which any extensions will clearly benefit only the late industrializers to the detriment of the group of potential industrializers. Like Ecuador, the potential industrializers must learn to circumvent the Agreement, since the limits imposed are on some of the key policies that are necessary to build up domestic industry. The strategy of using regional trade agreements is examined further later in this paper.

\subsection{Agreement on Textiles and Clothing (ATC)}

The Uruguay Round Agreement on Textiles and Clothing (ATC) left a very long transition period. And it is not at all clear that the developed countries will not attempt to extend product integration past 2005. Part of the reason that the industrialized countries are holding back on liberalizing textile flows has to do with the leverage it provides. Over the past three years, the United States has included textiles in a number of unilateral trade preferences that it grants to the developing countries. Textiles can now be exported duty free to the United States market from any country covered by the African Growth and Opportunity Act, 2000, and Caribbean Basin Trade Partnership Act, 2000. The desire by countries to become part of these groups gives the United States leverage over them. ${ }^{18}$ By bringing textiles into the WTO, the industrialized countries would lose this as a source of political leverage.

\footnotetext{
${ }^{18}$ Interview by Di Caprio (Washington DC, August 2002).
} 


\subsubsection{The latecomers}

Much of the pre-war manufacturing experience that was key to the eventual industrial success of the latecomers came from the production of cotton textiles and silks. While their textile industries did not become dynamic world players until after World War II, technology in this sector was not stagnant and facilitated capacity-building. It was in these sectors that foreign technicians first became common. Technology transfer often had its origins in the purchase of equipment and learning from the technicians who installed it, as in the case of Japan's earliest spinning mills (Amsden, 2001: 27). Textile production was the United States' key to the industrialization of the latecomers, since it was, in general, one of the first sectors to be successful against primary products.

\subsubsection{The potential industrializers}

The potential industrializers, on the other hand, do not all have textile industries, and many instead have the necessary historical manufacturing experience in other sectors. Even so, many of the countries in the group of potential industrializers have used textiles as a means of generating revenue and see it as useful for their industrial mix.

It is difficult to generalize about the usefulness of integrating products into the WTO framework, since the effects appear to be country specific. For example, Ecuador is outside the quota system and will therefore benefit as tariffs and quotas are removed. However, for those countries that fall under the international quota system, product integration has potentially detrimental results. Textile producers generally locate where production costs are lowest. Quotas often give countries an additional incentive with which to attract textile producers over and above low-cost labour. Once these quotas are gone, it is probable that profit-seeking producers will move to countries with lower costs or other incentives.

An additional reason why the rapid integration of textiles and clothing into the WTO may not necessarily benefit the group of potential industrializers comes from China, which has extensive capacity to manipulate the prices and production of textiles. As a result of Phase 3 integration, textile quota controls were removed from Category 666 (textile furnishings) in January 2002. China was able to halve the price of goods in this category (from US\$15 to US\$7 million) and to increase their production by 724 per cent from the levels of the previous year. ${ }^{19}$ Other countries in the group of potential industrializers simply cannot keep up with this capacity.

Another problem for the group of potential industrializers in making use of textiles as a means of industrialization is that now even their predecessors are raising barriers. More and more trade in goods is intra-regional. While most countries export the bulk of their textiles to the United States and the European Union, regional markets are also often important. However, this year, Brazil began limited textile imports from Asia. ${ }^{20}$ It appears that as the late industrializers move up the development scale, they are adopting the same sophisticated protectionist techniques as the developed economies.

\footnotetext{
${ }^{19}$ Data from the Pakistani Embassy (Washington DC, February 2003).

20 "Lula's message for two worlds", in The Economist. 1 February 2003: 32-33.
} 
The conclusion that we reach from this evidence is that, while the textile sector is an important source of revenue for many of the potential industrializers, it is problematic to assume that it will serve as an engine of growth. The problem is not in the WTO Agreement on Textiles and Clothing, but rather lies in the differential barriers of importing countries and the production capacity of exporting countries.

\subsection{Agreement on Agriculture}

Agriculture is a priority sector for many of the late industrializers. Many of them have competitive export sectors and are limited mainly by the continued protection of agriculture in the industrial countries. An example of this is the fact that the United States and the European Union invoked the special safeguard provision in the Agreement on Agriculture an exorbitant 399 times between 1995 and 1999 (Bertholet, 2001). Many of the potential industrializers also have competitive agricultural exports and would like to see them expand. However, disagreements over the use of agricultural subsidies put the two cohorts at odds.

\subsubsection{The latecomers}

The latecomers defined development as moving away from primary products and into the production of assets based on knowledge. The focus for them was to use agriculture as a means of moving away from dependence on it. However, many of these countries continue to define agriculture as a priority sector, since it does create revenue.

Those latecomers that had prosperous agricultural sectors were able to use agricultural revenues for other sectors. Taiwan (China) exploited agriculture to generate revenue for manufacturing diversification. Chile used the export of exotic fruits counter-seasonally to the North for the same purpose (Amsden, 2001: 291).

\subsubsection{The potential industrializers}

The group of potential industrializers has not necessarily defined development as moving away from primary products. And many continue to work towards the modernization of this sector.

Developing countries as a group are given greater leeway for non-compliance in terms of time extensions for the removal of agricultural subsidies. While in theory this will benefit them, in fact only the latecomers have sufficient revenue to subsidize agriculture.

Ecuador has pointed out that Colombia and Thailand have long maintained agricultural subsidies, such as a differentiated price of sugar for export industries, but it was only through the WTO that Ecuador gained the ability to challenge them. Peru has seconded the benefits of the ability to litigate subsidies through the Dispute Settlement Understanding 
(DSU), mentioning some recent successful cases, such as the sardines and scallops cases against the European Union, both of which were won by Peru. ${ }^{21}$ This is important because it illustrates that, in addition to simply having different views about the agreements, potential industrializers often block agreements that might help them in order to spur development in the short term.

The subsidy issue also limits innovation. Peru has pointed out that it is unable to modernize cotton production as the United States maintains subsidies, which makes it cheaper for Peru to import cotton. This is a potentially important problem, since countries in the same region tend to produce similar goods. Yet, as indicated above, the ability to subsidize is only available to the most successful of these countries. The continuation of subsidies will therefore promote goods produced by latecomers at the expense of their neighbours, which fall into the group of potential industrializers.

\subsection{Agreement on the Application of Sanitary and Phytosanitary Measures (SPS)}

The Agreement on the Application of Sanitary and Phytosanitary Measures (SPS) was adopted to regulate the manner in which governments can apply food safety and animal and plant health measures. Like TRIPs, it was formulated in an effort to standardize regulations between countries. While few countries argue that it forces them to achieve unreasonable standards, it has become one of the agreements that most clearly limits the strategies of developing countries because of capacity constraints.

\subsubsection{The latecomers}

Early in the Uruguay Round, there was concern that the SPS Agreement would force the upward harmonization of standards to the detriment of countries that could not fulfil them. This prediction has not been fully borne out. This is one case in which an WTO agreement has actually loosened the standards used by developed countries to limit imports of certain goods. Taking the example of the United States vs. Mexico Tuna-Dolphin Case, ${ }^{22}$ the United States was forced to allow tuna to be imported from Mexico, despite disagreeing with the manner in which they were caught. The latecomers were therefore actually operating under harsher rules respecting SPS during their industrialization, and do not appear to see this as a limit.

\subsubsection{The potential industrializers}

The limitations caused by the SPS Agreement for the group of potential industrializers have their origins more in capacity constraints than the Agreement itself. Interviewees mentioned that, in many cases, if a developed country refuses to allow imports of their products due to a health reason under the SPS, the exporting county often has limited

\footnotetext{
${ }^{21}$ DS12 and DS231.

${ }^{22}$ DS72.
} 
ability to counter such claims. Nigeria presented the example of the European Union banning the import of groundnuts as a result of finding a toxin in them. Nigeria cannot counterclaim, as it does not have the facilities to test for the toxin or to deal with it if it is found. Another example is the inability of Peru to export citrus fruit to the United States, which claims to have found a disease in the fruit and refuses to accept the results of Peruvian laboratories. It is too expensive to bring in other laboratories to carry out the testing. This prompted a Peruvian official to exclaim that, "We were good students, we lowered our barriers even before the WTO, why is this happening to us?"23

During their industrialization, the latecomers built up the capacity to test and deal with problems that fall into this category. For them, the SPS Agreement is beneficial because it loosens the import limits imposed by various countries. It is the countries which have not yet industrialized, those which are coasting on only one or two export industries, such as oil, which do not have the financial ability to build up scientific research units other than those that already exist. However, even the group of potential industrializers realize the importance of health measures and do not challenge the wording of the Agreement, despite the fact that they are clearly constrained by their capacity to test. Nigeria pointed out that the SPS Agreement "opened the door", but that until it develops the skill and expertise for testing, it will not be able to make use of its benefits.

\section{Constrained by safeguards}

The WTO makes a number of textual concessions to members which feel that their domestic industries are threatened by free trade. These include the Agreement on Subsidies and Countervailing Measures and the Anti-Dumping Agreement. Numerous authors have already pointed out that these are used primarily by developed countries. We examine below whether they have the potential to be used as tools for development by the industrializing countries.

\subsection{Anti-Dumping Agreement}

The Agreement on Implementation of Article VI of the General Agreement on Tariffs and Trade 1994 (or the Anti-Dumping Agreement) and the Agreement on Subsidies and Countervailing Measures have been hailed as two of the most important limitations on the development strategies of the developing countries. In a recent study, Anne Krueger (1999) points out that developing country exporters have suffered disproportionately. Both groups of countries say that these are measures of which they are not able to take advantage and which are being over-used against them. China points out that it is the biggest recipient of anti-dumping duties, which it cites as the biggest hindrance to trade.

Although the use of non-tariff barriers was eliminated in the Uruguay Round, they still exist in various forms. Developing countries complain that the excessive use of antidumping duties is just another manifestation of such barriers. As Grady and Macmillan point out, it appears that the "more advanced the economy, the more subtle a form that protectionism assumes" (1999: 22).

\footnotetext{
${ }^{23}$ Interview by Di Caprio (Geneva, December 2002).
} 


\subsection{Agreement on Subsidies and Countervailing Measures}

The strategic use of subsidies was one of the key development tools of the late industrializers. As many authors have noted, the list of actionable subsidies now includes precisely those used by the latecomers, and by the developed countries before them. The latecomers have been proactive in working for extensions of developing country exceptions and in pushing for subsidies to be actionable only above a certain limit. Peru points out that it is mainly the latecomers that are pushing for extensions to the time limits for developing countries to come into line with the Agreement. In particular, Colombia and Thailand want a seven-year extension.

\subsubsection{Non-actionable subsidies for research and redevelopment}

In addition to complaints about the adverse use of subsidies and other trade measures against them, the potential industrializers do not seem to be taking advantage of one of the key types of non-actionable subsidies, namely those for research and development. ${ }^{24}$

Latecomer countries focused heavily on research and development to expand and maintain their ability to stay at the forefront of technology. In six of the Latin American latecomer countries, the amount of R\&D expenditure increased by 40 per cent between 1990 and 1996. In 1996, these countries accounted for over 90 per cent of the estimated US\$13.7 million of R\&D spending in the Latin American and Caribbean region. ${ }^{25}$ Brazil, in particular, almost doubled its R\&D spending between 1990 and 1996. Mexico and Costa Rica notably shifted from being net importers to exporters of high technology goods during the period 1991-2000 (Hill, 2002). These increases are notable not only in view of their magnitude, but also because they began from an amazingly small base.

All of the potential industrializers have research institutes, but most are small and underfunded. Nigeria has several Government-run institutes related to agriculture, such as the Cassava Institute, and one for veterinary products. The Nigerians have had a recent success with one of their research groups, which has just sold a sickle cell drug to the United States. The Peruvian Government claims not to have any Government-run institutes, but to depend on the universities to do most of the work. This is typical of Latin American countries.

Across the board, the potential industrializers state that they do not have the money to provide subsidies and that they feel that the proposed extensions on the time limits for developing countries to come into line with the subsidies agreements are unnecessary and will only benefit the latecomers.

\footnotetext{
${ }^{24}$ Agreement on Subsidies and Countervailing Measures, Part IV, Article 8, Paragraph 8.2(a).

${ }^{25}$ These countries include Argentina, Brazil, Chile, Costa Rica, Mexico and Venezuela (Hill, 2000).
} 
The fact that subsidies are helping only those countries that can afford them, and hurting potential industrializers, which cannot afford to provide them, deserves more research. It is also a key problem if potential industrializers oppose efforts to extend time periods for developing countries on these grounds, as they may very well be painting themselves into a corner.

\section{Lack of developmental States}

The reader has by now gained the sense that the countries that have been called "potential industrializers" are not being adversely affected by many of the new limitations imposed by the WTO because they are not taking full advantage of the development strategies that are available to them

When asked about their industrial strategies, the potential industrializers do not seem to have any. The typical response is that they will see where business invests, and that will be the key sector. This hints that, regardless of the constraints imposed by WTO agreements, these countries do not have the same types of developmentally-focused governments that were key for the late industrializers.

Many of the potential industrializers have unstable political regimes and are countries that have seen great financial instability or war. Where their governments are democracies, this only adds to the instability. In this new constrained environment, progress simply cannot be expected to occur unaided without a government that is committed to development.

The WTO provides some hope in this respect. Many of the potential industrializers admit relief at the fact that the WTO agreements have tied the hands of their governments. Many of these countries do not have the luxury of a long-term ruling regime, such as the Partido Revolucionario Institucional (PRI) in Mexico or Park Chung Hee in the Republic of Korea. Although the late industrializers provide a model, the weakness of the governments in the potential industrializers indicates that it is a model that they would not have been able to follow regardless of constraints.

Some States, such as Ecuador and China, have shown a good deal of wile in dealing with the WTO. China became an observer to the GATT in 1982, but was able to draw out its negotiations long enough to be able to address WTO-illegal elements of its development policies before it was bound by the Agreement. Even as implemented, it is still claimed that many regulations are vague. According to a report by the United States Chamber of Commerce, "These gaps give regulators considerable, indeed excessive flexibility in how they will implement commitments" (Brilliant and Griffen, 2002). India seconded the importance of progressively taking down barriers when an official pointed out that it had not experienced detrimental effects from the WTO agreements, as it had opened progressively, not all at once. 
Developing countries have achieved success when working as a bloc. However, this was easier in the early days of the GATT. In 1947, there were 23 members of the GATT, while today there are $145 .^{26}$ As John Odell (2002) points out, even as recently as the Uruguay Round, many developing countries simply endorsed an agenda that was negotiated by other States. However, by 1999, developing countries such as Pakistan, Egypt and Malaysia had become very vocal in their desire for a new Director-General from their region.

The credibility of the governments of the late industrializers was also a key factor in their developmental success (OECD, 1994: 24). Many of the group of potential industrializers have unstable or weak regimes that may not necessarily be credible. This is one area in which the WTO can make up for a shortcoming by providing a framework for governments to follow, regardless of their political intentions. As Fernandez and Rodrik (1991) pointed out in their model of trade liberalization and reform, efficient reforms often do not take place because of the uncertainty regarding who will benefit. Acemoglu and Robinson (2001) continue this line of reasoning by arguing that the political systems that exist today cannot credibly commit to future policies, as they will be determined by whoever holds power in the future. As a result, inefficient redistribution persists. This argument can also be turned to explain the efficient actions of the late industrializers. In their case, many governments were strong and credible and able to direct protectionist policies in such a way that the initial inefficiency was worked through.

It is also important to remember that many of the decisions made by the late industrializers were as a result of international conditions. For example, Havrylyshyn and Alikhani (1989: 163) suggest that the high barriers to labour-intensive exports may have spurred faster industrial diversification than would otherwise have occurred. An OECD study (1994: 29) also points out that the first oil crisis in 1973 led several of the Asian economies to push earlier for higher value-added technologies in response to balance of payments difficulties. According to the statistics, the group of potential industrializers is shifting away from primary products more slowly than its predecessors.

\footnotetext{
${ }^{26}$ As of 5 February 2003.
} 
Table 2 - Changes in the product structure of selected developing country exports (\% share)

\begin{tabular}{lrrrr}
\hline & \multicolumn{2}{c}{ Primary products } & \multicolumn{2}{c}{ Manufactures } \\
& $1968-70$ & $1998-2000$ & $1968-70$ & $1998-2000$ \\
\hline Latecomers & & & & \\
Brazil & 89 & 43 & 10 & 55 \\
\hline Korea, Rep. Of & 24 & 9 & 76 & 89 \\
\hline India & 47 & 20 & 52 & 78 \\
\hline Taiwan, China & 35 & 5 & 64 & 95 \\
\hline Mexico & 74 & 15 & 26 & 85 \\
\hline Potential industrializers & & & & 22 \\
\hline Kenya & 88 & 77 & 12 & 18 \\
\hline Nigeria & 97 & 99 & 2 & 18 \\
\hline Tanzania & 87 & 79 & 13 & 9 \\
\hline Ecuador & 98 & 91 & 2 & 18 \\
\hline Peru & 99 & 64 & 1 & 31 \\
\hline Colombia & 91 & 69 & 9 & 62 \\
\hline Costa Rica & 81 & 38 & 25 & 33 \\
\hline Guatemala & 74 & 67 & 9 & \\
\hline Source: & & & & \\
\hline
\end{tabular}

Source: $\quad$ WTO, Annual Report 2002.

\subsection{Managing foreign investment}

While TRIMs has made many of the requirements that the developing countries had placed on foreign investors illegal, it does not preclude the use of programmes that encourage foreign investors to work with domestic industries. The UNCTAD World Investment Report 2001 was devoted to describing and promoting such schemes. However, while these are a good way of drawing foreign know-how from investment, the examples in the report are primarily those of higher-end late industrializers. It is unlikely that other countries in the group of potential industrializers will have the skill or capacity to undertake such programmes.

Since the flows of FDI to developing countries have been increasing rapidly in recent years, it is in the interests of all of the potential industrializers to manipulate FDI as much as they are allowed. Without the proper management of such resources, there is no indication that they will be the engine of industrial growth that some people claim.

As the World Investment Report 2001 points out, the amount of FDI that goes into mergers and acquisitions instead of new businesses is growing. This means that there is, in effect, a denationalization of these businesses. For the latecomers, this is not necessarily troublesome, since they have the internal capacity to maintain independent research and development facilities. However, for the group of potential industrializers, their firms are often not as highly developed as the foreign investing firms, and when they are taken over R\&D activities are shifted back to the investors' home country. This results in the draining of capacity. Peru has pointed out that foreign investment in plastics has crowded out most 
of its domestic producers. All of these examples follow Alexander Gerschenkron's observation that the later the industrialization, the more important the role played by FDI (see Amsden, 2001).

\subsection{Regional integration agreements}

It is also important to bear in mind alternatives that may enable potential industrializers to pursue strategies that mimic the late industrializers, but on a smaller scale. One possible option is the use of regional integration areas, as Ecuador did in the example provided earlier in order to maintain local content requirements for automobile production. Article XXIV of the GATT allows countries to establish customs unions and free trade areas. According to the World Bank, more than one-third of all international trade occurs within regional integration agreements (RIAs). ${ }^{27}$

A recent paper on the impact of NAFTA on research and development and total factor productivity (TFP) in Mexico concludes that trade with NAFTA partners has increased TFP and R\&D in Mexico to a degree that trade with other OECD nations has not (Wang and Schiff, 2003). The paper points out that NAFTA has been important in the level of technology diffusion that Mexico has been able to achieve.

It is important to distinguish between types of regional integration agreement, or in other words, whether they are South-South or North-South. As a representative of India noted in an interview, cooperation can be difficult, since many of the developing countries export the same goods. Several studies also show that, when goods are homogenous, South-South RIAs lower bloc welfare (Schill and Winters, 2003; World Bank, 2000).

Table 3 below illustrates the importance of regional export markets for latecomers. In almost every case, exports to their neighbours increased over the quarter century of their highest rates of growth. The errant case in the group is Mexico, which follows the trend of increasing exports to its neighbour. However for Mexico, the neighbour happens to be an industrial country, so its case is somewhat misleading.

${ }^{27}$ This increases to more than 50 per cent if Asia-Pacific Economic Cooperation (APEC) is included (World Bank, 2000). 
Table 3 - Direction of exports (\%)

\begin{tabular}{|c|c|c|c|}
\hline & United States & Europe & Local \\
\hline \multicolumn{4}{|c|}{ Brazil } \\
\hline & 26.2 & 43.5 & 11.7 \\
\hline & 18.6 & 32.2 & 18.1 \\
\hline - & 11.8 & 27.9 & 23.3 \\
\hline \multicolumn{4}{|c|}{ Mexico } \\
\hline & 71.2 & 11.1 & 10.5 \\
\hline - & 66.0 & 16.2 & 6.9 \\
\hline & 86.2 & 5.0 & 6.1 \\
\hline & Japan & United States & Local \\
\hline \multicolumn{4}{|c|}{ India } \\
\hline & 20.1 & 20.4 & 10.0 \\
\hline - & 25.3 & 20.3 & 10.7 \\
\hline - & 21.1 & 0.5 & 20.9 \\
\hline \multicolumn{4}{|c|}{ Korea, Rep. of } \\
\hline - & 41.4 & 27.7 & 7.0 \\
\hline - & 28.4 & 17.3 & 14.7 \\
\hline - & 21.5 & 13.7 & 34.3 \\
\hline \multicolumn{4}{|c|}{ Taiwan, China } \\
\hline - & 46.4 & 15.1 & 20.3 \\
\hline - & 36.6 & 11.0 & 17.7 \\
\hline - & 25.0 & 11.8 & 40.7 \\
\hline
\end{tabular}

\section{Towards a post-Washington Consensus trade regime}

It was noted above that, although the Washington Consensus is under siege, there is not yet an alternative. Some proposals are made below about the general outline of what such a trade regime might entail.

The most important aspect is that there must be a stronger alliance between the late industrializers and the group of potential industrializers. The late industrializers have the capacity and the force to push for change in WTO agreements, as evidenced by the proactive stance of Brazil and India. However, the potential industrializers need to work with them, rather than fighting against them, in order to ensure that the changes do not just benefit the latecomers. It is troubling that over half of the dispute settlement cases brought by potential industrializers are against the policies of other potential industrializers or of other developing countries. 
This also speaks to the need for a greater degree of developmentalism from the governments of potential industrializers. Without a clear plan, it is unlikely that even the best terms of WTO membership will "allow" them to develop. The governments of potential industrializers do not have the same developmental drive as their predecessors. This may be a result of domestic political dynamics, or of a widespread acceptance of the Washington Consensus as the proper role for governments. Without a government that has a clear development strategy, simply extending deadlines and allowing for subsidies that these governments cannot afford will only put them further behind.

Without developmentalist regimes and cooperation with latecomers, the potential industrializers will not benefit from extensions designed to help developing countries. They will be pushed back by the late industrializers, many of which are still classified as developing countries, and therefore qualify for the same extensions and rollbacks. As some of the examples in this paper illustrate, the late industrializers have the tools and the knowhow to take advantage of the available loopholes.

Existing policies in the WTO do not in fact have a development agenda. Regardless of the ability of countries to use measures such as green-light subsidies, there is a clear lack of recognition of the situation of those countries that do not yet have the capacity to use them. The main problems in the WTO are related to subsidies and investment measures. Yet these methods have been used by every country that has achieved industrialization. By precluding these types of policies for the newest group, the WTO is precluding sustainable industrial development.

This is not to say that the WTO does not offer opportunities. As the examples above show, potential industrializers are not late industrializers and in fact benefit from the structure imposed by the WTO. Nigeria points out that without the WTO it would have to negotiate bilaterally, which would take more resources, greater effort and giver rise to worse outcomes as a result of power differentials. Peru points out that things "often go wrong in Peru" and the WTO is a way of guaranteeing a stable environment for investors.

While a knee-jerk response to the WTO agreements is that countries should be allowed to use the same policies that were tolerated under the GATT regime, the conclusion reached in this paper is that this might cause more harm than good. In practice, too many allowances are made for "developing countries", with too little recognition of the capacity differences between them. It can only be expected that this gap will widen as accession agreements for the newest members become more and more stringent. For example, Vanuatu withdrew from negotiations altogether in 2002 on the basis that it was being requested to make excessive concessions in the bilateral negotiations. Brazil has called the current entry price of the WTO "mercantilism at its worst".

So, in answer to the question posed in the title of this paper, yes the WTO does allow for industrialization policies, but not to such a degree that these policies can lead to development for the group of potential industrializers in the long term. And for as long as governments lack a clear-cut strategy, the degree of freedom in the WTO is redundant. But, as Pakistan has optimistically pointed out, while the overall environment is constraining, we will ultimately benefit from the system, it will just be in a different way than our predecessors. ${ }^{28}$

${ }^{28}$ Interview by Di Caprio (Washington DC, February 2003). 


\section{Bibliography}

Acemoglu, Daron, and Robinson, James. 2001. "Inefficent redistribution", in American Economic Review. 91: 938-963.

Amsden, Alice. 2001. The rise of 'the rest': Challenges to the west from late-industrializing economies. New York, Oxford University Press.

----. 1990. Asia's next giant: South Korea and late industrialization. New York, Oxford University Press.

Amsden, Alice, Tschang, Ted, and Goto, Akira. 2001. Do foreign companies conduct $R \& D$ in ceveloping countries? Working Paper No. 14. Asian Development Bank Institute.

Bertholet, Jacques. 2001. Some theoretical and factual clarifications in order to get to a fair Agreement on Agriculture in the WTO. WTO Symposium on issues confronting the world trading system, 6-7 July. Geneva.

Bhagwati and Krueger. 1973. "Exchange control, liberalization and economic development," in American Economic Review. 63(2), May: 419-427.

Bora, Bijit, Lloyd, Peter, and Pangestu, Mari. 2000. Industrial policy and the WTO. Policy Issues in International Trade and Commodities, Study Series No. 6. UNCTAD.

Brilliant, Myron, and Griffen, Leslie. 2002. First steps: A United States Chamber report on China's WTO progress. United States Chamber of Commerce. China WTO Implementation Working Group.

Coe, David, Helpman, Elhanan, and Hoffmaister, Alexander. 1997. "North-South R\&D spillovers", in Economic Journal. 107(440).

Epsztein R. 1998. Primeiros efeitos da nova Lei brasileira de Propriedade Industrial sobre a dinâmica de desenvolvimento dos setores farmacêutico e de biotecnología. Rio de Janeiro. COPPE/UFRJ, doctoral thesis.

Feldstein, Martin. 1997. International capital flows. NBER Research Conference report, 17-18 October.

Fernandez, Raquel, and Rodrik, Dani. 1991. "Resistance to reform: Status quo bias in the presence of individual-specific uncertainty", in American Economic Review. 81(5), December: 1146-55.

Grady, Patrick, and Macmillan, Kathleen. 1999. Seattle and beyond: The WTO Millennium Round. Ottawa, Global Economics.

Grossman, Gene, and Helpman, Elhanan. 1991. Innovation and growth in the global economy. Cambridge, MIT Press.

Havrylyshyn, Oli, and Alikhani, Iradj. 1989. "Changing comparative advantage and trade among developing countries", in Black, John, and MacBean, Alasdair (eds.), Causes of changes in the structure of international trade, 1960-1985. Basingstoke, Macmillan.

Hill, Derek. 2002. Latin America: High-tech manufacturing on the rise, but outpaced by East Asia. Nation Science Foundation InfoBrief. August.

----. 2000. Latin America: R\&D spending jumps in Brazil, Mexico, and Costa Rica. National Science Foundation, Division of Science Resources Studies, NSF 00-316.

Krueger, Anne. 1999. The developing countries and the next round of multilateral trade negotiations. World Bank Working Paper No. 2118.

NSF. 2001. Human resource contributions to US science and engineering from China. Issue Brief 01311. 12 January. National Science Foundation. 
Odell, John, S. 2002. "The Seattle impasse and its implications for the World Trade Organization", in The political economy of international trade law: Essays in honor of Robert E. Hudec. Cambridge University Press.

OECD. 1996. Regionalism and its place in the multilateral trading system. Paris.

----. 1994. The benefits of free trade: East Asia and Latin America. Trade Policy Issues. Paris.

Schiff, Maurice, and Winters, Alan. 2003. Regional integration and development. World Bank and Oxford University Press.

Schott, Jeffery (ed.). 2000. The WTO after Seattle. Washington DC, Institute for International Economics.

Shapiro, Helen. 1994. Engines of growth: The State and transnational auto companies in Brazil. Cambridge University Press.

Singh, Ajit. 1996. "The post-Uruguay Round world trading system, industrialization, trade and development: Implications for the Asia-Pacific developing countries", in Expansion of trading opportunities to the year 2000 for Asia-Pacific developing countries: Implications of the Uruguay Round and adaption of export strategies. New York and Geneva, UNCTAD.

Tussie, Diana. 1987. The least developed countries and the world trading system: A challenge to the GATT. London, Francis Pinter.

UNCTAD. 2002a. Trade and development report 2002. New York and Geneva.

----. 2002b. World investment report 2002: Transnational corporations and export competitiveness. New York and Geneva.

----. 2001. World investment report 2001: promoting linkages. New York and Geneva.

Wang, Yanling, and Schiff, Maurice. 2002. Regional integration and technology diffusion: The case of the North America Free Trade Agreement. World Bank Working Paper No. 3132.

Weiler, J.H.H., and Sungjoon Cho. 2003. International and regional law: The law of the WTO through the cases.

World Bank. 2000. Trade blocs. World Bank Policy Research Report. Washington DC.

----. 1995. World development report 1995: Workers in an integrating world. Oxford, New York, Oxford University Press. 


\section{Policy Integration Department Working Papers prepared for the World Commission on the Social Dimension of Globalization}

No. 16 International finance: Meeting the needs of people in developing countries, José Guilherme Almeida dos Reis

No. 17 The gender dimensions of the globalization of production, Stephanie Barrientos, Naila Kabeer and Naomi Hossain

No. 18 Social exclusion in the context of globalization, Jan Breman

No. 19 Gender and globalization: A macroeconomic perspective, Çağatay Nilüfer and Ertük Korkurt

No. 20 Globalization, social exclusion, and work: with special reference to informal employment and gender, Marilyn Carr and Martha Chen

No. 21 Resources for social development, Anthony Clunies Ross

No. 22 Does the new international trade regime leave room for industrialization policies in the middle-income countries?, Alisa DiCaprio and Alice Amsden

No. 23 Social dimension of globalization in Latin America: Lessons from Bolivia and Chile, Alvaro García Hurtado

No. 24 Globalization: Social impact and policy actions: A partly annotated bibliography, Bernhard Gunter and Rolph van der Hoeven

No. 25 The social dimension of global production systems, Susan Hayter

No. 26 Reforming global economic and social governance:

a critical review of recent programmatic thinking, Jeremy Heimans

No. 27 Corporate social responsibility: An issues paper, Michael Hopkins

No. 28 Upgrading in global value chains, John Humphrey

No. 29 Implications of globalization and economic restructuring for skills development in Sub-Sahara Africa, Richard K. Johanson

No. 30 The outcome and impact of the main international commissions on development issues, Frédéric Lapeyre

No. 31 Globalization and structural adjustment as a development tool, Frédéric Lapeyre

No. 32 Globalization and perceptions of social inequality, Malte Luebker

No. 33 The changing structure of trade linked to global production systems: What are the policy implications?, William Milberg

No. 34 Corporate social responsibility: An overview of principles and practice, Jill Murray

No. 35 Inclusive development strategy in an era of globalization, Ignacy Sachs

No. 36 Social consequences of the globalization of the media and communications sector: Some strategic considerations, Seán Ó. Siochrú

No. 37 Globalization, history and international migration - A view from Latin America, Andrés Solimano

No. 38 Towards a different kind of globalization, or how the anti-globalizers view the world, Gijsbert van Liemt 